\title{
Prospective Teachers' Attitude towards the Use of ICT : An Empirical Approach in Pakistan.
}

\author{
Dr. Tariq Hussain \\ Assistant Professor \\ Institute of Education and Research \\ University of the Punjab \\ Lahore, Pakistan
}

\begin{abstract}
The quality of education depends upon the knowledge and attitude of teachers towards the use of ICT through which teaching-learning process has been converted in the global education system to accomplish long term and short term educational goals. The study purpose was to explore prospective teachers' attitude towards the use of ICT. The nature of the study was descriptive and based on cross sectional survey by taking a sample of 450 prospective teachers from the Institute of Education and Research through two stage sampling technique (census \& convenient). The information and Communication Technology (ICT) scale was adapted. The original version of the scale was developed by Albirini in 2006 consisting of 80 items.After pilot study the ICT scale was consisted of 31 items on five-point Likert-Type scale. Data were analyzed by using statistical techniques. Results showed that prospective teachers have positive attitude towards the use of ICT. A significant difference in the attitude of female and male prospective teachers towards the use of ICT was observed. On the other hand, there was no significant difference in the attitude of prospective teachers in terms of locality, program (morning \& self-supporting) and different departments. It was recommended that training programs should be conducted by the educational administration in the institutions to enhance prospective teachers' ICT skills.
\end{abstract}

Keywords: ICT, Attitude, Prospective Teachers

\section{Introduction and Background}

Information and Communication Technology (ICT) is the demand of our present educational system and information world. Teacher's interest towards information communication technology is crucial for the future of the students. In the present state internet is commonly used through which one can get desired information in seconds. Therefore, it is a good time when every teacher must be aware of information communication technology. ICT has appeared as one of the most important phase of human life.ICT enlarges the access of education through which learning can possible at every place and anytime.We can get the access of e-materials seven days a week, 24 hours a day. The use of telecommunication devices has improved the teacher and learner interaction with ease and accessibility. There are numerous resources abundant on internet. Teaching and learning has been improved by using video clips, audio sounds, and visual presentation instead of printed material. It has been possible only through the use of ICT that teachercentered approach in our educational system is shifting into learner-centered approach (Sanchez\& Aleman, 2011).All communication methods or applications encompassing: computer, cellular phones, network, hardware and software, radio, television, satellite broadcasting systems and so on, furthermore, many other facilities and compliances linked with them, such as video conferencing and distance learning fall under the parasol term ICT(Rouse, 2005).

The needs of existing modern societies have been affected by the advancements in ICT which brought the remarkable changes in twenty first century. ICT is playing very important role in our daily lives and education systems.So, it is necessary to implement the use of ICT in educational organizations to make the students expert in terms of their knowledge and skills because ICT is the requirementof 21 century's learner. In order to associate the existing technology in teaching and learning today's educational institutions are trying to modify their educational programs and classroom needs.In this regard, active approval of modern technologies is needed to make students expert in their knowledge of specific subject areas, to endorse significant learning and improve specialized output (Tomei, 2005).

Attitude of prospective teachers towards ICT is important in the present educational system because without knowledge of ICT a teacher can't be a perfect teacher (Saxenaet.al, 2009). Worth of teaching and learning increased through providing great privilege to the use of information and communication technology in teacher education (Wee \&Bakar, 2006). 
Different studies on attitude of teacher trainees towards ICT teaching exposed that the issues like locality and gender of teacher-trainees influenced their attitude towards the information and communication technology teaching (Gupta, 2017; Suganthi, 2013).Exhibition of three-dimensional visuals could be possible for the teachers through the use of Information and communication technologieswhich is not possible with the conventional two-dimensional means.Goktas, Yildirim, and Yildirim (2009) believed that a mutual term ICTs is used for variety of technologies ranging from computer hardware and software systems, internet, radio, television, mobile phones, and cameras etc.In general, we can say that it is a group of technologies categorized to access, store and distribute wide variety and quantity of information.

The use of ICT can be increased in the classroom by boosting the competency level of teachers. Integration of technology in future teacher education programs can be possible by choosing and applying the most effective policies to train prospective teachers. (Goktas, 2008). The importance of ICT is specified in most curriculum documents to boost the prospective teachers to use these technologies. On the other hand, teacher training programs are necessary in order to integrate ICT in their teaching (Markauskaite, 2006). Combination of ICTs tools provided help to teachers to use appropriate collaborative method for learners (Newhouse, Trinidad, \& Clarkson, 2002). According to Bailey et al.(2004), the appropriate use of ICTs also enabled the teachers in storing, organizing and demonstration of information.

Mostly teachers are not well aware and well trained about the appropriate use of technologies in their teaching. The reasons of inappropriate use of technology in the education system can be the lack of proper training regarding the use of new technology, insufficiency in skills to integrate technology in daily activities and lack of resources (Pelgum, 2001).In present era teachers are facing many difficulties in teaching learning process. Resolving these problems various new technological tools are available to them.However, it is also necessary for teachers to study to practice and add this technology in their teaching approaches (Robinson \&Latchem, 2003). In modern era teachers will not focused upon only their routine activities but it will become necessary for them to update their knowledge and skills of fresh technologies to use these technologies in their profession (Carlson \&Gadio, 2002).ICT is more likely to be used by those teachers who possess a strong bond with their students to make them more advance in using modern technologies (Collis \& Jung, 2003). Teacher can play vital role in alter the teacher centered approaches into student centered approaches through the effective use of ICTs. (Carlson \&Gadio,2002).

Developing countries are facing many difficulties in the implantation of ICTs in their education system. Meanwhile Pakistan is also one of those developing countries facing many difficulties in almost every fieldas well as education and haplessly, far behind from the battle of progress. There is a need of comprehensive strategies to brilliantlyincorporate technology into teaching and learning at public sector level. Load shedding, poor telecommunication links, insignificant school buildings are the major problems need to be addressed by educational administration which is essential to get success in education and the every field of life.Physical and infrastructural facilities are present in most of the institutes in countryside areas of Pakistan which are helpful to ICTs.To make Pakistan successful in this century, there is a need to improve ICT by implementing effective and robust policies in Pakistan.

\section{Objectives of the Study}

The objective of the study was to explore the prospective teachers' attitude towards ICT.

\section{Research Questions}

- What is the attitude of prospective teachers towards ICT?

- What is the difference between female and male prospective teachers'attitude towards ICT?

- Is there any significant difference between the attitude of rural and urban prospective teachers towards ICT?

- Is there any significant difference between the attitude of morning and self-supporting program prospective teachers towards ICT?

- Is there any significant difference among attitude of prospective teachers of all departments in IER towards ICT?

\section{Research Methodology}

The study was quantitative in nature. Descriptive research design based on a cross-sectional survey was used to conduct this study. The sample of the 450 prospective teachers was selected by using two stage sampling technique from the Institute of Education and Research.At first stage, all the departments were selected through census sampling technique. At second stage, 50 (25 from each class) prospective teachers were selected through convenient sampling technique from each department. The adaptive version of (ICT) scale which was developed by the Albirini in 2006was used.The original version of the scale was consisted of 80 statements under 6 factors.But the adaptive version of the scale was consisted of 31 items under four factors on five point likert type scale. The scale showed the sound reliability $(\alpha=0.84)$. 
Data were analyzed by using Statistical Package for Social Sciences (SPSS) version 21. Mean scores and standard deviation (SD) of the respondents on (ICT) scale were calculated by applying descriptive statistics while t-test and ANOVA was applied to compare the attitude of prospective teachers towards ICT in terms of gender, locale, program and departments by applying inferential statistical technique.

\section{Data Analysis}

RQ1. What is the attitude of prospective teachers towards ICT?

Table 1 Descriptive Statistics

\begin{tabular}{lllll}
\hline & Min & Max & Mean & SD \\
\hline OpinionaboutICT & $\mathbf{6 . 0 0}$ & $\mathbf{3 0 . 0 0}$ & $\mathbf{2 2 . 4 6}$ & $\mathbf{4 . 7 5}$ \\
UseofICT & $\mathbf{1 1 . 0 0}$ & $\mathbf{5 5 . 0 0}$ & $\mathbf{4 1 . 5 8}$ & $\mathbf{7 . 3 7}$ \\
LearningthroughICT & $\mathbf{8 . 0 0}$ & $\mathbf{4 0 . 0 0}$ & $\mathbf{2 9 . 9 1}$ & $\mathbf{5 . 3 3}$ \\
Skills & 6.00 & $\mathbf{3 0 . 0 0}$ & $\mathbf{2 3 . 8 1}$ & $\mathbf{4 . 4 5}$ \\
Total & $\mathbf{3 1 . 0 0}$ & $\mathbf{1 5 5 . 0 0}$ & $\mathbf{1 1 7 . 9 1}$ & $\mathbf{1 9 . 2 1}$ \\
\hline
\end{tabular}

Table indicates that the mean score of prospective teachers' attitude towards "Use of ICT" sub-scale was greater $(\mathrm{M}=41.58, \mathrm{SD}=7.37)$ than all other sub-scales of attitude towards ICTrespectively $(\mathrm{M}=22.46, \mathrm{SD}=4.75 ; \mathrm{M}=29.91$, $\mathrm{SD}=5.33 ; \mathrm{M}=23.81, \mathrm{SD}=4.45$ ). Overall prospective teachers exhibited the positive attitude towards the ICT (M= 117.91, $\mathrm{SD}=19.21$ ).

RQ2. What is the difference between female and male prospective teachers' attitude towards ICT?

Table 2 Comparison of attitude towards ICT sub-scales in terms of gender of the prospective teachers

\begin{tabular}{|c|c|c|c|c|c|c|c|}
\hline \multirow[t]{2}{*}{ Variables } & \multicolumn{2}{|c|}{ Male (83) } & \multicolumn{2}{|c|}{ Female (367) } & \multirow[t]{2}{*}{$T$} & \multirow[t]{2}{*}{$d f$} & \multirow[t]{2}{*}{$P$} \\
\hline & $M$ & $S D$ & $M$ & $S D$ & & & \\
\hline Opinion about ICT & 22.96 & 4.32 & 22.46 & 4.84 & .87 & 448 & .39 \\
\hline Use of ICT & 43.40 & 7.19 & 41.26 & 7.35 & 2.51 & 448 & .01 \\
\hline Learning through ICT & 30.40 & 4.96 & 29.90 & 5.41 & .78 & 448 & .43 \\
\hline Skills & 24.42 & 4.13 & 23.88 & 4.50 & 1.19 & 448 & .24 \\
\hline Overall Attitude toward ICT & 121.1 & 17.9 & 117.2 & 19.4 & 1.67 & 448 & .01 \\
\hline
\end{tabular}

Table indicates that the mean score of male prospective teachers was greater in all four subscales $(\mathrm{M}=22.96, \mathrm{SD}=$ $4.32 ; \mathrm{M}=30.40, \mathrm{SD}=4.96 ; \mathrm{M}=4.42, \mathrm{SD}=4.13)$ than the mean score of female prospective teachers $(\mathrm{M}=22.46, \mathrm{SD}=4.84$; $\mathrm{M}=29.90, \mathrm{SD}=5.41 ; \mathrm{M}=23.88, \mathrm{SD}=4.50)$. There was no significant difference between the female and male prospective teachers' attitude in three subscales of attitude towards ICT ["Opinion about ICT" (t(448) $=.87, \mathrm{p}=.39)$, "Learning through ICT" $(\mathrm{t}(448)=.78, \mathrm{p}=.43)$ and skills $(\mathrm{t}(448)=1.19, \mathrm{p}=.24)$. On the other hand, a significant difference was between male and female prospective teachers'attitude in the subscale "use of ICT" $(\mathrm{t}(448)=2.51$, $\mathrm{p}=.01)$. Overallthere was a significant difference between the attitude of male $(\mathrm{M}=121.1, \mathrm{SD}=17.9)$ and female prospective teachers $(\mathrm{M}=117.2, \mathrm{SD}=19.4)$ towards ICT $[\mathrm{t}(448)=1.67, \mathrm{p}=.01]$. It may be inferred that female prospective teachers have less positive attitude towards ICT than the male prospective teachers.

RQ3. Is there any significant difference between the attitude of rural and urban prospective teachers towards ICT?

Table 3 Comparison of ICT attitude factors on the basis of locality of respondents.

\begin{tabular}{llllllll}
\hline Variables & \multicolumn{2}{l}{ Rural (123) } & \multicolumn{2}{l}{ Urban (327) } & T & df & P \\
& $\mathrm{M}$ & $\mathrm{SD}$ & $\mathrm{M}$ & $\mathrm{SD}$ & & & \\
\hline Opinionabout ICT & 22.52 & 5.01 & 22.43 & 4.66 & .17 & 448 & .87 \\
Use of ICT & 41.77 & 7.44 & 41.50 & 7.35 & .34 & 448 & .74 \\
Learning throughICT & 29.59 & 5.85 & 30.14 & 5.12 & -.98 & 448 & .33 \\
Skills & 24.27 & 3.76 & 23.75 & 4.66 & 1.10 & 448 & .27 \\
Overall Attitude towards ICT & 118.2 & 19.3 & 117.8 & 19.2 & .15 & 448 & .88 \\
\hline
\end{tabular}

Table depicts that the mean score of rural areas prospective teachers was greater in three subscales $(\mathrm{M}=22.52$, $\mathrm{SD}=5.01 ; \mathrm{M}=41.77, \mathrm{SD}=7.44 ; \mathrm{M}=24.27, \mathrm{SD}=3.76)$ than the urban areas prospective teachers $(\mathrm{M}=22.43,4.66 ; \mathrm{M}=41.50$, $\mathrm{SD}=7.35 ; \mathrm{M}=23.75, \mathrm{SD}=4.66)$.However, the mean score of rural areas prospective teachers was smaller in learning through ICT subscale $(M=29.59, S D=5.85)$ than the urban areas prospective teachers $(M=30.14, S D=5.12)$. 
Overall attitude towards ICTmean score of rural areas prospective teachers was also greater $(\mathrm{M}=118.2, \mathrm{SD}=19.3)$ than the urban areas prospective teachers $(\mathrm{M}=117.8, \mathrm{SD}=19.2)$. The results of t-test indicate that there was statistically no significant difference between the attitude of rural and urban areas prospective teachers in all subscales and overall attitude towards ICT[ $\mathrm{t}(448)=.17, \mathrm{p}=.87 ; \mathrm{t}(448)=.34, \mathrm{p}=.74 ; \mathrm{t}(448)=-.98, \mathrm{p}=.33 ; \mathrm{t}(448)=1.10, \mathrm{p}=.27 ; \mathrm{t}(448)=.15, \mathrm{p}=.88]$. Rural and urban areas prospective teachers have almost the same level of attitude towards the use of ICT.

RQ4. Is there any significant difference between the attitude of morning and self-support program prospective teachers towards ICT?

Table 4 Comparison of attitude towards ICT on the basis of the morning and self-support program of prospective teachers

\begin{tabular}{llllllll}
\hline Variables & \multicolumn{2}{l}{ Morning (226) } & \multicolumn{2}{l}{ Self-Support (224) } & $t$ & $d f$ & $P$ \\
& $M$ & $S D$ & $M$ & $S D$ & & & \\
\hline Opinion about ICT & 22.00 & 4.83 & 22.91 & 4.63 & -2.02 & 448 & .04 \\
Use of ICT & 40.85 & 7.92 & 42.30 & 6.70 & -2.09 & 448 & .04 \\
Learning through ICT & 29.87 & 5.43 & 30.11 & 5.23 & -.48 & 448 & .63 \\
Skills & 23.58 & 4.41 & 24.21 & 4.44 & -1.49 & 448 & .14 \\
Overall Attitude towards ICT & 116.3 & 19.9 & 119.6 & 18.4 & -1.78 & 448 & .08 \\
\hline
\end{tabular}

Results publicized that the mean score of morning program prospective teachers was smaller in all four subscales and overall attitude towards ICT $(\mathrm{M}=22.00, \mathrm{SD}=4.83 ; \mathrm{M}=40.85, \mathrm{SD}=7.92 ; \mathrm{M}=29.87, \mathrm{SD}=5.43 ; \mathrm{M}=23.58, \mathrm{SD}=4.41 ;$ $\mathrm{M}=116.3, \mathrm{SD}=19.9)$ than the self-support program prospective teachers $(\mathrm{M}=22.91, \mathrm{SD}=4.63, \mathrm{M}=42.30, \mathrm{SD}=6.70$; $\mathrm{M}=30.11, \mathrm{SD}=5.23 ; \mathrm{M}=24.21, \mathrm{SD}=4.44 ; \mathrm{M}=119.6, \mathrm{SD}=18.4)$. On the other hand, a statistically significant difference was found between the attitude of morning and self-support program prospective teachers in the "opinion about ICT" and "use of ICT" subscale [ $\mathrm{t}(448)=-2.02, \mathrm{p}=.04 ; \mathrm{t}(448)=-2.09, \mathrm{p}=.04]$. However, there was no significant difference between the morning and self-support program prospective teachers in the rest of the two subscales $[\mathrm{t}(448)=-.48, \mathrm{p}=$ $.63 ; \mathrm{t}(448)=-1.49, \mathrm{p}=.14$ ] and overall attitude towards ICT [ $\mathrm{t}(448)=-1.78, \mathrm{p}=.08$ ]. In other words, morning and selfsupport program prospective teachers showed the same level of attitude towards the use of ICT.

RQ5. Is there any significant difference among attitude of prospective teachers of all departments in IER towards ICT?

Table 5 Comparison of prospective teachers' attitude towards ICT of all departments

\begin{tabular}{lllllll}
\hline Departments & $\mathrm{N}$ & Mean & SD & df & F & P \\
Business Education & 50 & 3.67 & .69 & 441 & 1.70 & .094 \\
Secondary Education & 50 & 3.99 & .33 & 441 & & \\
ELTL & 50 & 3.87 & .79 & 441 & & \\
MERA & 50 & 3.80 & .48 & 441 & & \\
Elementary Education & 50 & 3.79 & .50 & 441 & & \\
Technology Education & 50 & 3.62 & .75 & 441 & & \\
Islamic Education & 50 & 3.81 & .64 & 441 & & \\
MS.ED & 50 & 3.91 & .55 & 441 & & \\
ECE & 50 & 3.77 & .63 & 441 & & \\
Total & 450 & 3.80 & .61 & 449 & & \\
\hline
\end{tabular}

Table illustrate that the mean score of Secondary Education department (SEC) prospective teachers was highest $(\mathrm{M}=3.99, \mathrm{SD}=.33)$ followed by the mean score ofMS.ED department prospective teachers $(\mathrm{M}=3.91, \mathrm{SD}=.55)$, ELTL department prospective teachers $(\mathrm{M}=3.87, \mathrm{SD}=.79)$, ISL department prospective teachers $(\mathrm{M}=3.81, \mathrm{SD}=.64)$, MERA department prospective teachers $(\mathrm{M}=3.80, \mathrm{SD}=.48)$, ELE department prospective teachers $(\mathrm{M}=3.79, \mathrm{SD}=.50)$, $\mathrm{ECE}$ department prospective teachers $(\mathrm{M}=3.77, \mathrm{SD}=.63)$, MBE department prospective teachers $(\mathrm{M}=3.67, \mathrm{SD}=.69)$, and the mean score of Master of Technology education department prospective teachers' attitude towards ICT was lowest $(\mathrm{M}=3.62, \mathrm{SD}=.75)$. On the other hand, the results of ANOVA test indicate that there was statistically no significant difference among the prospective teachers' attitude towards ICT of all departments [F $(441)=1.70, \mathrm{p}=.09]$. It may be inferred that the prospective teachers of all departments have the same level of attitude towards the use of ICT.

\section{Conclusion}

Conclusively, it can be said that the prospective teachers of Institute of Education and Research (IER) showed positive attitude towards ICT.Majority of prospective teachers agreed that Information and Communication Technology (ICT) has positive effect on their learning. They want to learn more about new technologies for their future job and profession. 
All the prospective teachers agreed that the use of ICTs is result oriented, advantageous and important for the development of the education. So, it is concluded that most of the responses were positive. Results further revealed that the female prospective teachers showed less positive attitude towards ICT than the male prospective teachers. However, there was no significant difference found in the attitude of prospective teachers towards ICT with respect to locality, program and departments.

\section{Discussion}

The possibilities of information and communication technology (ICT) as an educational instrument in teacher education programs had been well proven in the present century. This study investigated the attitude of prospective teachers towards information and communication technology (ICT) at the Institute of Education and Research. The results of this study revealed that the attitude of prospective teachers towards the use of ICT was positive. The literature revealed the evidence of positive attitude of prospective teachers as quoted by the researchers (Gupta, 2017;Yusuf\&Balogun, 2011; Sekar, \& Lawrence, 2015).

\section{Recommendations}

- University administration should also provide opportunities in terms of up gradation of information technology (IT) laboratories with provision of latest technologies (laptops, LED projectors and smart boards etc.) in the institutions.

- Information and Communication Technology (ICT) awareness programs should be made compulsory to educate the prospective teachers at all level by teacher training institutions.

- Teacher Educators should work as role model for Prospective Teachers by using ICT in teaching learning process.

- Educational management should organize workshops/seminars for the awareness of prospective teachers about the usefulness of ICT.

- Training programs should be organized by teacher training institutions in collaboration withICTrelated institutions like Pakistan telecommunication authority (PTA) to enhance ICT skills.

\section{References}

Albirini, A. (2006). Teachers' attitudes toward information and communication technologies: The case of Syrian EFL teachers. Computers \& Education, 47(4), 373-398.

Bailey, L., Day, C., Day, T., Griffin, A., Howlett, P., Kane, M., ...\& Perfect, K. (2004). Using ICT in schools: Addressing teacher workload issues. ISBN, 1(84478), 341.

Carlson, S., \&Gadio, C. T. (2002).Teacher professional development in the use of technology. Technologies for education, 118-132.

Goktas, Y., Yildirim, S., \&Yildirim, Z. (2009). Main barriers and possible enablers of ICTs integration into pre-service teacher education programs. Journal of Educational Technology \& Society, 12(1).

Goktas, Y., Yildirim, Z., \&Yildirim, S. (2008). A review of ICT related courses in pre-service teacher education programs. Asia Pacific Education Review, 9(2), 168-179.

Gupta, M. (2017). Prospective teacher's attitude towards the use of ICT: A comparative study between CCS University, meerut and kurukshetra University, kurukshetra. Educational Quest: An International Journal of Education and Applied Social Sciences, 8(1), 81.

Jung, I., \& Collis, B. (2004).Uses of information and communication technologies in teacher education.In Teacher education through open and distance learning (pp. 187-208). Routledge.

Markauskaite, L. (2006). Gender issues in preservice teachers' training: ICT literacy and onlinelearning. Australasian Journal of Educational Technology, 22(1), 1.

Newhouse, P., Trinidad, S., \& Clarkson, B. (2002). Quality pedagogy and effective learning with information and communication technologies (ICT): A review of the literature. Manuscript prepared for the Western Australian Department of Education. Perth: Specialist Educational Services. Retrieved from http://www.det. wa. edu. au/education/cmis/eval/downloads/pd/litreview. pdf.

Pelgrum, W. J. (2001). Obstacles to the integration of ICT in education: results from a worldwide educational assessment. Computers \& education, 37(2), 163-178.

Robinson, B., \&Latchem, C. (Eds.).(2003). Teacher education through open and distance learning (Vol. 3).Psychology Press.

Rouse, M. (2005). Distance learning (e-learning). Retrieved from WhatIs.com: http://whatis. techtarget. com/definition/distance-learning-e-learning.

Sánchez, J. J. C., \&Alemán, E. C. (2011).Teachers’ opinion survey on the use of ICT tools to support attendance-based teaching. Computers \& Education, 56(3), 911-915. 
Saxena, A., Sun, M., \& Ng, A. Y. (2009). Make3d: Learning 3d scene structure from a single still image. IEEE transactions on pattern analysis and machine intelligence, 31(5), 824-840.

Sekar, J., \& Lawrence, A. S. (2015).Attitude of B. Ed. Students towards Information and Communication Technology (ICT). Online Submission, 1(8), 785-787.

Suganthi, M. (2013).Attitude of B. Ed. students towards information and communication technology. Indian Journal of Applied Research, 3(9), 167-169.

Tomei, L. A. (2005). Taxonomy for the technology domain.In Taxonomy for the Technology Domain (pp. 89-108).IGI Global.

Yusuf, M. O., \&Balogun, M. R. (2011). Student-teachers' competence and attitude towards Information and communication technology: A case study in a Nigerian University. Contemporary Educational Technology, 2(1), 18-36.

Wee, M. C., \&Zaitun, A. B. (2006). Obstacles towards the Use of ICT Tools in Teaching and Learning of Information Systems in Malaysian Universities. Int. Arab J. Inf. Technol., 3(3), 203-209. 